(C) 2021 Katedra Białorutenistyki UW. Wydanie w otwartym dostępie na licencji CC BY-NC-ND (https://creativecommons.org/licenses/by-nc-nd/4.0/deed.pl)

ACTA ALBARUTHENICA 21: 2021

DOI: 10.32612/uw.18988091.2021.21.pp.293-296

\title{
Joanna Getka, Jolanta Darczewska, Na drodze do wol- ności. Białoruska partyzantka kulturowa w przestrzeni publicznej i w Internecie, Wydawnictwa Uniwersytetu Warszawskiego, Warszawa 2021, 328 s.
}

Wielokulturowość i wielojęzyczność, płynność granic, wzajemne przenikanie się, przechodzenie od jednego języka do drugiego - to cechy pogranicza, dlatego Białoruś często jest traktowana jako pogranicze między Wschodem a Zachodem. Sprzyja temu położenie geopolityczno-cywilizacyjne - skrzyżowanie cywilizacji zachodniej i rosyjskiej. Na wszystkie zjawiska uwarunkowane kontaktami kulturowo-językowymi nakładają się czynniki społeczne, co ma istotny wpływ na kształtowanie się tożsamości narodowej i kulturowej Białorusinów.

Autorki monografii prześledziły ostatnie wydarzenia na Białorusi, które spowodowały znaczne przyspieszenie w budowaniu społeczeństwa obywatelskiego w tym kraju. Joanna Getka i Jolanta Darczewska przygotowały spójną publikację, uważnie i wszechstronnie analizując obserwowane zjawiska, uwzględniając przy tym nie tylko aspekt kulturowo-lingwistyczny, ale i uwarunkowania zewnętrzne (historyczno-polityczne, etniczno-narodowościowe, wyznaniowe). Główną uwagę zwróciły na podziemną działalność kulturalną Białorusinów prowadzoną w przestrzeni publicznej i w Internecie, której celem jest odzyskanie wolności oraz zbudowanie państwa niepodległego i demokratycznego poprzez upowszechnienie dziedzictwa przodków oraz kultywowanie wypracowanych przez nich wzorców zachowań i wartości.

W recenzowanej monografii Autorki omówiły 26-letnią rusyfikacyjną politykę Aleksandra Łukaszenki jako kontynuację polityki okresu sowieckiego, główną uwagę koncentrując na wydarzeniach 2020 r. i jednocześnie wskazując na najważniejsze okresy oporu społecznego i walki opozycji białoruskiej, dążącej do białorutenizacji kraju oraz budowania państwa demokratycznego.

Poszukując sposobów desowietyzacji tożsamości zbiorowej, Białorusini znaleźli je w potencjale kulturowym, który dzięki wsparciu niezależnych portali internetowych zdołał skonsolidować szerokie kręgi społeczeństwa. Aby uzmysłowić subwersywny potencjał białoruskiej kultury niezależnej, przeciwstawiającej się symbolicznej władzy państwa, Autorki dla porównania przedstawiły także ideologiczny potencjał władz Republiki Białorusi 
(s. 21-22). Postawiły sobie za cel pokazanie, jak i w jakim stopniu działania subwersywne przekształcają „świadomość i postawy społeczeństwa biernego, monologicznego w światopogląd aktywnego społeczeństwa dialogu" (s. 22), co z powodzeniem zrobiły drogą głębokiej analizy współczesnej kultury białoruskiej „na styku obrazu, słowa, performansu w różnych wymiarach - rzeczywistym i wirtualnym" (s. 19).

Wykorzystana $\mathrm{w}$ recenzowanej pracy baza materiałowa jest bardzo bogata. Składają się na nią liczne źródła ilustracyjne: memy, zdjęcia, grafiki cyfrowe, strony internetowe, materiały audiowizualne; wykaz haseł w kilku językach - rosyjskim, białoruskim, białorusko-rosyjskiej „trasiance”, angielskim, francuskim, hiszpańskim; wykaz utworów powstałych na fali wydarzeń 2020 r., również w kilku językach - białoruskim, rosyjskim, białoruskim i rosyjskim, angielskim, także zagranicznych artystów. Tak szeroko zakrojony i obszernie zaprezentowany materiał egzemplifikacyjny jest istotnym walorem monografii.

Recenzowana praca znakomicie wpisuje się w coraz bogatszą literaturę dotyczącą badań nad kształtowaniem się białoruskiej tożsamości narodowej i kulturowej. Zresztą Autorki są doskonale zorientowane w wielojęzycznej (polskiej, białoruskiej, rosyjskiej, angielskiej, niemieckiej) interdyscyplinarnej literaturze naukowej obejmującej językoznawstwo, literaturoznawstwo, kulturologię, socjologię, historię, politologię, którą szeroko cytują w swoich wieloaspektowych badaniach, zestawiając perspektywy różnych dyscyplin, co jest dodatkowym walorem monografii.

Autorki swobodnie poruszają się po tym jakże trudnym i skomplikowanym pod względem narodowościowo-językowym terenie, wywiązując się bez zastrzeżeń z podjętych zadań badawczych. Takie kontekstowe ujęcie tytułowego zagadnienia podnosi poznawczą wartość pracy. Novum pracy polega na interdyscyplinarnym podejściu do tematu, a także, co bardzo ważne, na dogłębnej analizie wydarzeń odbywających się na naszych oczach, na umiejętnym ukazaniu roli kultury w kształtowaniu białoruskiej tożsamości narodowej i budowaniu społeczeństwa obywatelskiego, co jest pozytywnym wyróżnikiem recenzowanej monografii na tle innych publikacji, ujmujących wydarzenia $\mathrm{z}$ jednej perspektywy - najczęściej historycznej lub socjologicznej.

Przyjęte w monografii założenia badawcze wpłynęły na jej kształt. Rozprawa składa się z dwóch części.

Część pierwsza pt. Białoruska droga donikąd (s. 25-91) zawiera dokładny opis Łukaszenkowskiej polityki tożsamości oraz białoruskiego społeczeństwa oporu jako skutku tejże polityki, analizę białoruskich mitów i stereotypów tożsamościowych (że A. Łukaszenka jest gwarantem pokoju, stabilności i suwerenności Białorusi, że Białorusini są podatni na dezinformację i propagandę, że język rosyjski na Białorusi jest językiem kultury wysokiej, 
że język białoruski jest narzędziem politycznym opozycji, że białoruskość jest wtórna wobec słowiańskości, rosyjskości i radzieckości, mit o wasalnym stosunku Białorusinów wobec Rosji, mit o tutejszości) skonfrontowanych $\mathrm{z}$ faktami oraz nowy dyskurs tożsamościowy.

Z kolei w części drugiej pt. Białoruska partyzantka kulturowa na drodze do wolności (s. 93-262) zawarta jest analiza dwóch światów: systemu Białoruś i społeczeństwa protestu, transparent jest przedstawiony jako medium antysystemowej kontestacji i kontrpropagandy, muzyka oporu jest generatorem emocji i nośnikiem wartości kulturowych, sztuka uliczna służy przejmowaniu przestrzeni publicznej, a cyfrowe formy - budowaniu tożsamości oporu.

Jak słusznie zauważają Autorki, ingerencja władz w sferę kultury „doprowadziła do podziału artystów na przedstawicieli kultury oficjalnej, którzy współpracują z władzą i mogą liczyć na określone przywileje" oraz środowisko niezależne, które „działając w podziemiu i stosując zróżnicowane metody partyzanckie zdołało wywalczyć sobie ważne miejsce w kulturze białoruskiej” (s. 41). „Mecenat” państwa nad kulturą nie sprzyja jej rozwojowi, służy jedynie „ochronie i legitymizacji władz Białorusi” (s. 44). Z kolei społeczeństwo oporu, „obalając mity dominujące dotąd w mainstreamie, dokonuje desowietyzacji i derusyfikacji oficjalnej polityki tożsamości, a także odbrązowienia, delegitymizacji Łukaszenki" (s. 64).

Autorki pokazały, że treści prezentowane na transparentach, w różnych formach sztuki ulicznej (graffiti, murale, plakaty, rzeźby, obrazy mało- i wielkoformatowe, różnego rodzaju formy performatywne, np. teatr, happeningi, flash moby, instalacje), a także w tekstach piosenek budują więzi społeczne, przyczyniają się do oddolnej białorutenizacji oraz do innego spojrzenia nie tylko w przyszłość kraju, ale również do innej percepcji historycznej, zmieniają pamięć zbiorową społeczeństwa, zakorzeniając ją w zamierzchłych czasach Księstwa Połockiego czy Wielkiego Księstwa Litewskiego. „Formy tych interakcyjnych działań, nowoczesne, atrakcyjne dla uczestników, bez wątpienia wpisują się $\mathrm{w}$ proces budowania społeczeństwa obywatelskiego, czemu towarzyszy autentyczna troska o jego kondycję" (s. 261).

Bardzo istotne znaczenie ma pokazanie, że w humorystycznych działaniach kulturowych zawarto poważny cel - światowa opinia publiczna usłyszała protest Białorusinów przeciwko fałszowaniu wyborów oraz dotychczasowej polityce rusyfikacji i sprawowaniu autorytarnych rządów. Analiza upublicznionych w sieci prac „prowadzi do wniosku o dwóch białoruskich światach: świecie systemu z Łukaszenką na czele i świecie społeczeństwa oporu” (s. 226). Zauważone i szczegółowo omówione przez Autorki „przewartościowania będą się utrwalać, wzmacniając wyraźny już obywatelski projekt białoruskiej tożsamości zbiorowej" (s. 268). 
Dodatkowym walorem monografii jest przejrzystość pracy i jasność wywodu: są tabele (prezentujące dwie formuły tożsamości białoruskiej, główne wyróżniki strategii subwersywnych systemu i ich dekonstrukcji, funkcje memów, język haseł na transparentach oraz utworów białoruskich, procent respondentów wskazujących białoruski jako język komunikacji codziennej, liczbę Białorusinów i Rosjan w świetle spisów ludności...), wypunktowane podsumowania oraz dużo fotografii unaoczniających opisywane wydarzenia.

Autorki przytaczają ogromną liczbę nazwisk osób zaangażowanych $\mathrm{w}$ opisywane wydarzenia, $\mathrm{i}$ - co jest bardzo istotne - zgodnie $\mathrm{z}$ ich brzmieniem w języku białoruskim. Nazwiska białoruskie stwarzają duży problem z kilku powodów: 1) podawane są naprzemiennie $\mathrm{w}$ transkrypcji z języka białoruskiego lub rosyjskiego, a w paszportach Białorusinów częsty jest zapis $w$ transkrypcji angielskiej; 2) $w$ języku polskim nie ma alternacji $u: w$ (błrus. ŭ:w - Галанаў - Галанава), co zmusza do zapisu nazwisk męskich w przypadkach zależnych z zachowaniem $\breve{u}$ (Hałanaŭ - Hałanaŭa - zamiast $\breve{u}$ niezgłoskotwórczego w pisowni polskiej można stosować $u$ ); 3) problem innej natury stwarza białoruskie akanie, które powoduje, że męskie imię Janka < Janko w języku polskim może być odczytane jako żeńskie. Zdarza się, że to samo nazwisko zapisywane jest w kilku wersjach, co dotyczy przede wszystkim odzwierciedlenia białoruskiego bilabialnego $в(w)$, np. Lawon Wolski (w tekście opracowania) i Lavon Volski (w odsyłaczach, ponieważ autor tak się podpisał po własnym tekstem, zgodnie z zapisem w paszporcie). Przy tak dużej liczbie nazwisk przytaczanych w tekście monografii nie udało się Autorkom uniknąć potknięć, np. Nina Szudłoŭskaja (s. 2) zamiast Nina Szydłoŭskaja, lecz takie nieliczne potknięcia natury technicznej nie umniejszają znaczenia recenzowanej pracy.

Monografia $\mathrm{Na}$ drodze do wolności: białoruska partyzantka kulturowa $w$ przestrzeni publicznej i $w$ Internecie jest cenna pod względem naukowym i poznawczym - uzupełnia wiedzę o najnowszych wydarzeniach na Białorusi oraz roli kultury $\mathrm{w}$ przyspieszonym ostatnio procesie kształtowania się tożsamości Białorusinów, jak i edukacyjnym - może być cennym źródłem informacji dla pracowników i studentów (doktorantów) nie tylko o zainteresowaniach białorutenistycznych.

Nina Barszczewska nbarszcz@uw.edu.pl 
